\section{Pleas made for science spy}

\section{Paris}

THE French League of Human Rights has decided to take up the case of Rolf Dobbertin, a plasma physicist at the Centre National de la Recherche Scientifique (CNRS), who was sentenced in June this year for spying for East Germany. Last month, the case provoked an open letter condemning the magistrate's decision from 18 members of the Académie des Sciences and the Collège de France, including Nobel laureates JeanMarie Lehn and François Jacob. Although Dobbertin admits having had relations with East German intelligence, the documents he sent were widely available, unclassified preprints of scientific articles.

Dobbertin was born in the former German Democratic Republic and began working in a CNRS laboratory at the University of Paris VII in 1962. In 1979 he was arrested by French counterintelligence under Article 80 (III) of the Penal Code, for acts of "intelligence with agents of a foreign power that are harmful to the military or diplomatic situation of France or to its essential economic interests". Remanded in custody for four years, Dobbertin appeared before a now-defunct military court in 1981. After other court appearances, he was finally released on bail by an appeal court in 1983 pending his trial. In June this year he was finally tried and sentenced to 12 years imprisonment.

At a recent press conference held by French League of Human Rights, it emerged that scientists are less upset by the plight of Dobbertin - although the sentence was felt to be "excessive" - than by the apparent assault the court ruling makes on the freedom to disseminate scientific information. At Dobbertin's trial, Professor René Pellat, president of the CNRS, confirmed that the documents recorded on the microfilm were "explicitly destined for the general scientific public" and that passing them on was "like sending a newspaper". At the appeal court hearing, in 1983, the prosecution lawyer admitted the documents were public, but said "the confidential or secret nature of the supplied documents is of no interest in characterizing the crime".

According to J. Micheli, of the Committee for the Liberation of R. Dobbertin, the trial "was indirectly a trial of the free circulation of scientific information". And speaking at the offices of French League of Human Rights last week, Professor Y. Queré, a physicist at the Académie des Sciences, said "the tradition of exchange between scientists dates back to the Renaissance. It is one of the basic conditions for the development of science".

It seems that it was Dobbertin's use of microfilm and the fact that his correspon- dents were secret agents rather than scientists that upset the French authorities. Although scientists calling for Dobbertin's release do not defend his unusual actions, they claim he has committed no crime. Professor E. Schatzman, of the Academy of Sciences, said that Dobbertin is a theoretical physicist and that, although there could be potential applications from his research field, "there is a wide gap between a formula and its application". Yves Jouffa, president of French League of Human Rights, says "he is not accused of spying but of having contact with intelligence of a foreign power. How can he be condemned to 12 years in prison without having passed any secrets?"

In a letter addressed to the French newspaper Libération and sent from prison, Dobbertin defends his use of spy

\section{UNIVERSITIES FUNDING COUNCIL}

\section{London}

THE disarray in funding arrangements for universities in the United Kingdom was compounded by strong language last Friday after an emergency meeting of the Committee of Vice-Chancellors and Principals (CVCP). In an open letter to Lord Chilver, Chairman of the Universities Funding Council (UFC). CVCP Chairman Sir Edward Parkes criticized the UFC's earlier rejection of the efforts of universities to comply with the UFC's own new arrangements for apportioning funds as "a serious blow to the effective management of the universities."

Under the UFC's new 'bidding'system (see Nature 348, 3; 1 November 1990), universities told the UFC how many students they wished to teach in each subject up to mid-1995, and the price at which students could be taught. The UFC said it would then allocate funds over the four-year period according to its assessment of these bids.

Universities duly tendered their bids, but on 23 October, UFC Secretary Finlay Scott wrote to university vice-chancellors expressing "disappointment" that 93 per cent of bids for student places for 1994-95 were pitched at the 'guide prices' set by the UFC, and effectively suspending further discussion on university funding until after the 1991-92 grant is set in February. The bids assume that student numbers will grow by 19 per cent by 1995 .

The CVCP's emergency meeting was held on 2 November to consider this new move. In view of the fact that the UFC declares that it must be satisfied that the government's desire for expansion does not compromise academic standards, technology: "the dissemination of science using documentary film, practised by libraries the world over" is not a medium "distinctive of espionage", he says.

Apart from the "general principle" of scientific freedom, the academicians' letter protests against Dobbertin's sentence. "Coming over 15 years after the deeds concerning a state which has practically ceased to exist, while, over the past seven years, the accused has been able freely to continue his research activity at CNRS, the extremely heavy 12-year prison sentence makes this trial belong to another age".

A petition for Dobbertin's release has received over 800 signatures and scientists have been sending preprints to Dobbertin in prison.

A delegation from the French League of Human Rights will meet President François Mitterrand shortly to ask for Dobbertin's release and pardon.

Peter Coles

\title{
Sparks fly in funding muddle
}

Parkes writes that "it would have been irresponsible for institutions to bid below the guide price in all but a few cases".

In the meantime, universities may take matters into their own hands rather than wait until the UFC allocates next years' grants. University College (UCL), a constituent college of the University of London, is thinking of raising a levy on students in Medicine and Law to augment fees paid on students' behalf by the government.

Dr Stephen Montgomery, Director of External Relations at UCL, stresses that the college is still discussing the concept as one of several ideas to raise money. "No decisions have been made at this time", he says. Like many other colleges, UCL's financial future is "in a state of uncertainty" following the UFC's 23 October letter.

In the latest issue of UCL's monthly newsletter, UCL's Provost Dr Derek Roberts blames the government for creating a climate in which universities are expected to pick up the bill for the government's aim to increase student numbers. In this way, he says, the government "wishes to be seen as a concerned facilitator whilst we attract the flak". He reserves his greatest ire for the "misinformed" government Public Accounts Committee and its criticism of university management.

"How any bunch of politicians has the nerve to accuse another group of incompetence in the light of successive governments' mismanagement of the UK economy for the last century would be hilarious if it were not so serious", he writes. 